\title{
Preliminary value chain analysis of gum and resin marketing in Ethiopia
}

\author{
Issues for policy and research
}

Habtemariam Kassa', Berihun Tefera² and Girmay Fitwi ${ }^{3}$

\begin{abstract}
Summary
The production of gums and resins in Ethiopia falls far short of its potential, even though the export volume and revenue from these dry-forest products have significantly increased during the past decade. However, consistently low prices mean producers have little economic incentive to manage dry forests responsibly. Actions are required at various levels to enable both the country and producers to obtain better prices for gums and resins. Ethiopia's federal and state governments must work on product and market development, which will require data on the production and marketing aspects of the gums and resins subsector.
\end{abstract}

This policy brief presents findings of studies conducted in 2007 and 2010 with the aim of filling knowledge gaps in the long-term trends of production and marketing and the current status of the value chain, focusing mainly on the structure, conduct and performance of natural gums and resins marketing in Ethiopia. The studies focussed on Tigray type gum olibanum (frankincense), which accounts for more than $90 \%$ of the export volume of gums and resins. To assess trends in production and marketing, secondary data were gathered and analysed. The Structure Conduct Performance (SCP) framework of value chain analysis was adopted, and data were collected using rapid market appraisal, where key informants and market actors along the chain were interviewed.
Findings indicate that the volumes of gums and resins produced and marketed over the years are characterised by inconsistency. During the past 5 years, however, the total volume of exports has risen sharply. During the past 10 years, domestic and export markets accounted on average for about $40 \%$ and $60 \%$ of the total marketed volume, respectively. The share of producers from the marketing margin of gums and resins ranged from 19\% to $75 \%$, and tended to be lower than that for exporters and wholesalers, particularly when the marketing channels are long and producers are not organised in cooperatives. For example, producers' marketing margin for Tigray type frankincense was 34.5\% in 2007 and 19.1\% in 2010, compared with $41.1 \%$ and $31.4 \%$, respectively, for exporters or wholesalers.

It is necessary to improve the efficiency of the market for producers and increase their share of the profits if they are to have an economic incentive to responsibly manage dry forests, which have vital environmental and ecological benefits for Ethiopia. Encouraging producers to form cooperatives and exporters to form an association is suggested as one way to increase their capacity for producing more and better-quality products, to add value to raw products and to boost their bargaining power. Studying options for appropriate governance of access to resources and the marketing chain is recommended in order to create economic incentives for producers to manage dry forests responsibly.

1 CIFOR, P.O. Box 5689, Addis Ababa, Ethiopia, h.kassa@cgiar.org

2 Department of Rural Development, College of Agriculture and Environmental Sciences, Bahir Dar University, Bahir Dar, Ethiopia, berihunt2@gmail.com

3 Natural Gums Processing and Marketing Enterprise, P. O. Box 62322, Addis Ababa Ethiopia, fitwi_girmay@yahoo.com 


\section{Introduction}

Economically important gums and resins exported from Ethiopia include gum olibanum (frankincense, known in Amharic as Itan) produced from Boswellia species, gum Arabic from Acacia senegal, gum talha from A. seyal, gum drepanolobium from A. drepanolobium, gum myrrh (or simply myrrh, called Kerbe in Amharic) from Commiphora myrrha, and gum oppoponax (known in Amharic as Abeked) from C. guidotti. The most important of these are frankincense, gum Arabic and myrrh. There are three types of frankincense: frankincense produced from Boswellia papyrifera in the Tigray, Amhara and Beneshangul Gumz regions (locally known as Tigray type Itan), frankincense from B. rivae and B. microphylla (locally known as Ogaden type Itan and produced in south-eastern Ethiopia), and frankincense from B. neglecta (locally referred to as Borena type Itan, mainly from southern Ethiopia) (Fitwi and Lemenih 2011). These dry-forest products are the major export products of Ethiopia's forestry sector. Although the country's export volume and revenue have increased in recent years (Lemenih and Kassa 2011a), the production level remains much lower than its estimated potential. This indicates that Ethiopia has not yet managed to benefit fully from this resource, due to a range of production, marketing and institutional shortcomings (Lemenih and Kassa 2011b). A major reason the production volume falls short of its potential is that producers obtain very low prices for their products. At the same time, there is rapid land use change and deforestation of dry-forest areas. For example, from the 1970s to 2000, the area in Tigray covered by B. papyrifera reportedly shrank by $35.3 \%$ (Wilson 1977, DoPED 2009). Recent studies by CIFOR in the Metema district of Amhara Region showed a 25\% decline in forest cover during the past 3 decades. The situation will only worsen, as there are no successful plantation establishments of this species. In Amhara Region, individual households do not have the right to tap Boswellia trees. Only those households that are organised into cooperatives and have approved concession rights can. Thus, few cooperatives have been established in the major producing districts. People who are not members of cooperatives have very little interest in managing the forest for gum production. Preventing local producers from tapping trees deprives them of a potential source of income and diminishes both the value of the forests for local people and their interest in conserving it. Indeed, this policy may accelerate degradation and conversion of forestland to other uses. The Tigray and Amhara Regional
Administrations have begun to address the situation. If communities are to manage forests responsibly, they must have guaranteed access to forest resources with a concomitant responsibility to sustainably manage the resource. Such an arrangement would help create amongst producers an economic incentive to produce frankincense. However, intervening in the marketing of forest products to ensure farmers receive higher marketing margins requires better understanding of the value chain of these products (Mesfin et al. 2007). This study was conducted to analyse the value chain from production to consumption and to make important research, development and policy recommendations. This brief was prepared based on a rapid market assessment study conducted in 2007 and in 2010 that assessed the value chain structure, conduct and performance of natural gums and resins marketing from Ethiopia with emphasis on Tigray type gum olibanum.

\section{Methods}

The study was conducted from August to October 2007, and again during the same months in 2010. Information was collected from secondary sources and from various agents involved in the production, processing and marketing of natural gums, including wholesaling, retailing and exporting enterprises and individuals. The study adopted the commodity approach of agricultural marketing, which focuses on the flow of a commodity through different channels according to different marketing functions. Porter's Value Chain Structure Conduct Performance (SCP) framework was used to assess the value chain. 'Value chain' refers to a set of value-adding activities through which a product passes from the design to the consumption stages (McCormick and Schmitz 2002). It represents a chain of activities for a firm operating in a specific industry (at firm level), or the physical representation of the various processes that are involved in producing goods and services (at industrial scale). It has also been described as consisting of the full range of activities that are required to take a product from its conception, through its origin, sourced raw materials and intermediate inputs, marketing, distribution and support to the end consumers (Institute of Development Studies 2002). Therefore, the main and supportive actors in the value chain and the flow of the commodity through different channels were mapped by the market value chain structure analysis, the market conduct examined by evaluating the behaviour of these actors and the market performance analysed using price margin analysis. 


\section{Major findings}

\subsection{Inconsistency characterises long-term trends in production and export marketing}

Time series data on the amount of gums and resins collected for export by all companies were difficult to obtain. However, information from the state-owned Natural Gums Processing and Marketing Enterprise (NGPME) clearly shows that the amount collected fell significantly in some years because of security-related issues in the country (in the late 1980s) and restrictions imposed by regional governments when the authorities anticipate over-tapping or recognise the need for trees to be rested. This restriction is not based on studied management plans but on assumed damages from extended tree tapping. This inconsistency in the volume of gums collected indicates problems related to either supply and demand or to management of the resource base. These aspects merit closer investigation (Figure 1).

NGPME is a state-owned actor that dominated the gum export market in the 1970s and 1980s. Since the mid-1990s, a number of exporting companies have emerged to become important players. More than 30 companies are engaged in exporting gums and resins. The total export volume shows consistent increases over time, growing from 1648 tonnes in 1999/2000 to 4612 tonnes in 2007/08 (Figure 2). Of the total export volume of gums and resins from the country during 1999/2000 to $2007 / 2008$, the share of the state-owned enterprise
NGPME dropped from $42 \%$ in $2001 / 02$ to $24 \%$ in $2004 / 05$, with an average of $35 \%$.

\subsection{Both domestic and export markets are important}

Available information about local markets relates only to gum olibanum, as local markets for other gums and resins are under-developed and poorly documented. The 10-year average figure from NGPME shows that the domestic market accounts for about $40 \%$ of the total marketed volume (Table 1). Inconsistencies are also observed in the proportion of gums and resins sold on the domestic and export markets.

\subsection{Market structure}

To view the market structure, the value chain is mapped to provide a visual representation of the stages in the chain and the connections between various primary value chain activities and support activities by relevant actors (McCormick and Schmitz 2002). The structure of gums and resins marketing in Ethiopia is shown in Figure 3.

Very small proportions of gum myrrh and gum oppoponax enter the local market, as most of these highvalue products go to neighbouring countries, in particular Kenya and Somalia. Gum olibanum, particularly the Tigray type, enters the legal market and much of it is exported; it constitutes more than $90 \%$ of the export volume of all gums and resins. In 2009, China began importing Grade

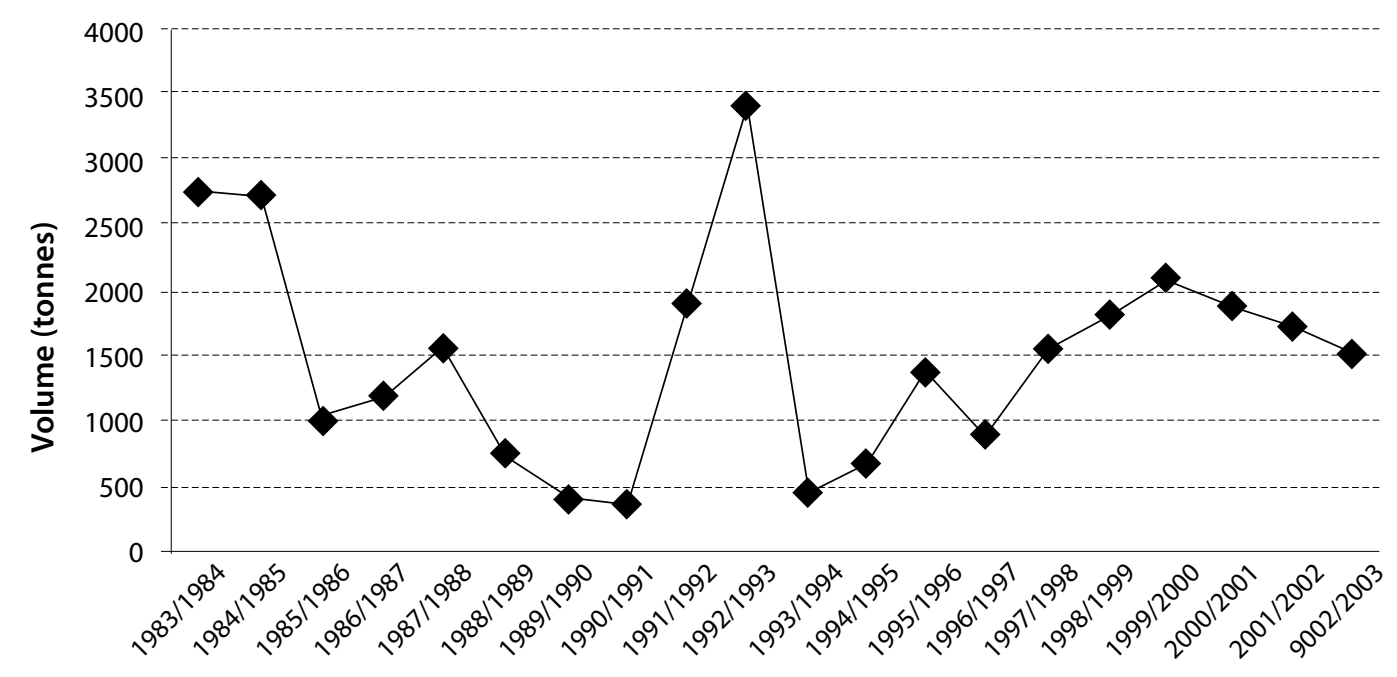

Production year

Figure 1. Volume of gums and resins produced by NGPME from 1983/84 to 2002/03 


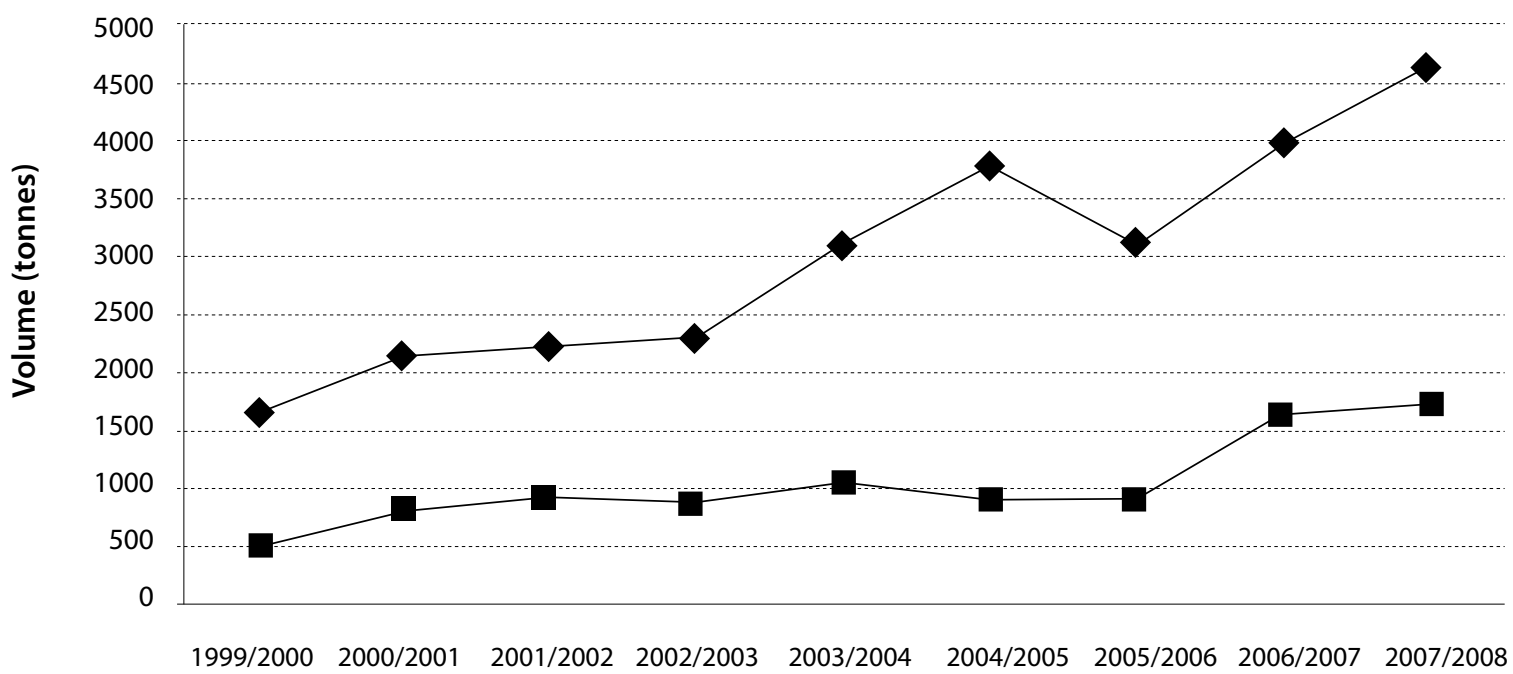

\section{Production year}
Total exports (tonnes)
- Exported by NGPME (tonnes)

Figure 2. Total national exports and the volume of exports by NGPME from 1999/2000 to 2007/08

Table 1. Total production, domestic and export market volumes of NGPME from 1999/2000 to 2008/09.

\begin{tabular}{|c|c|c|c|c|c|c|c|}
\hline \multirow{2}{*}{ Production year } & \multirow{2}{*}{$\begin{array}{l}\text { Production } \\
\text { (tonnes) }\end{array}$} & \multirow{2}{*}{$\begin{array}{l}\text { Total sales } \\
\text { (tonnes) }\end{array}$} & \multirow{2}{*}{$\begin{array}{c}\text { Store (to and from) } \\
\text { (tonnes) }\end{array}$} & \multicolumn{2}{|c|}{ Export market sales } & \multicolumn{2}{|c|}{ Domestic market sales } \\
\hline & & & & (tonnes) & $(\%)$ & (tonnes) & (\%) \\
\hline 1999/2000 & 1802 & 2243 & -441 & 515 & 33.0 & 1728 & 77.0 \\
\hline $2000 / 2001$ & 2084 & 1661 & 423 & 815 & 49.1 & 846 & 50.9 \\
\hline $2001 / 2002$ & 1882 & 1355 & 527 & 944 & 69.7 & 411 & 30.3 \\
\hline $2002 / 2003$ & 1744 & 1643 & 101 & 883 & 53.7 & 760 & 46.3 \\
\hline $2003 / 2004$ & 1502 & 1673 & -171 & 1053 & 62.9 & 620 & 37.1 \\
\hline $2004 / 2005$ & 1370 & 1550 & -180 & 906 & 58.5 & 644 & 41.5 \\
\hline $2005 / 2006$ & 1038 & 1563 & 525 & 922 & 59.0 & 641 & 41.0 \\
\hline $2006 / 2007$ & 1474 & 2126 & -652 & 1465 & 68.9 & 661 & 31.1 \\
\hline $2007 / 2008$ & 1544 & 2039 & -495 & 1738 & 85.2 & 301 & 14.8 \\
\hline $2008 / 2009$ & 1970 & 1768 & -202 & 1381 & 78.1 & 387 & 21.9 \\
\hline Average & 1641 & 1762 & -57 & 1062 & 61 & 670 & 39 \\
\hline
\end{tabular}

4 products (the second lowest quality grade), which previously had not been exported. Hence, currently frankincense of all quality grades is available for export except Grade 5, the lowest grade, which is sold locally.

As indicated in Figure 3, there are 2 main groups collecting gums and resins from trees in the dry forests.
The first group consists of employed labourers. They are experienced tappers organised into groups locally known as squadras. The squadra leader manages the group and reports to a coordinator whose role, just like a commission agent's, is to recruit and manage workteams. The coordinators assemble the gums and resins collected by hired labourers on behalf of the companies or 


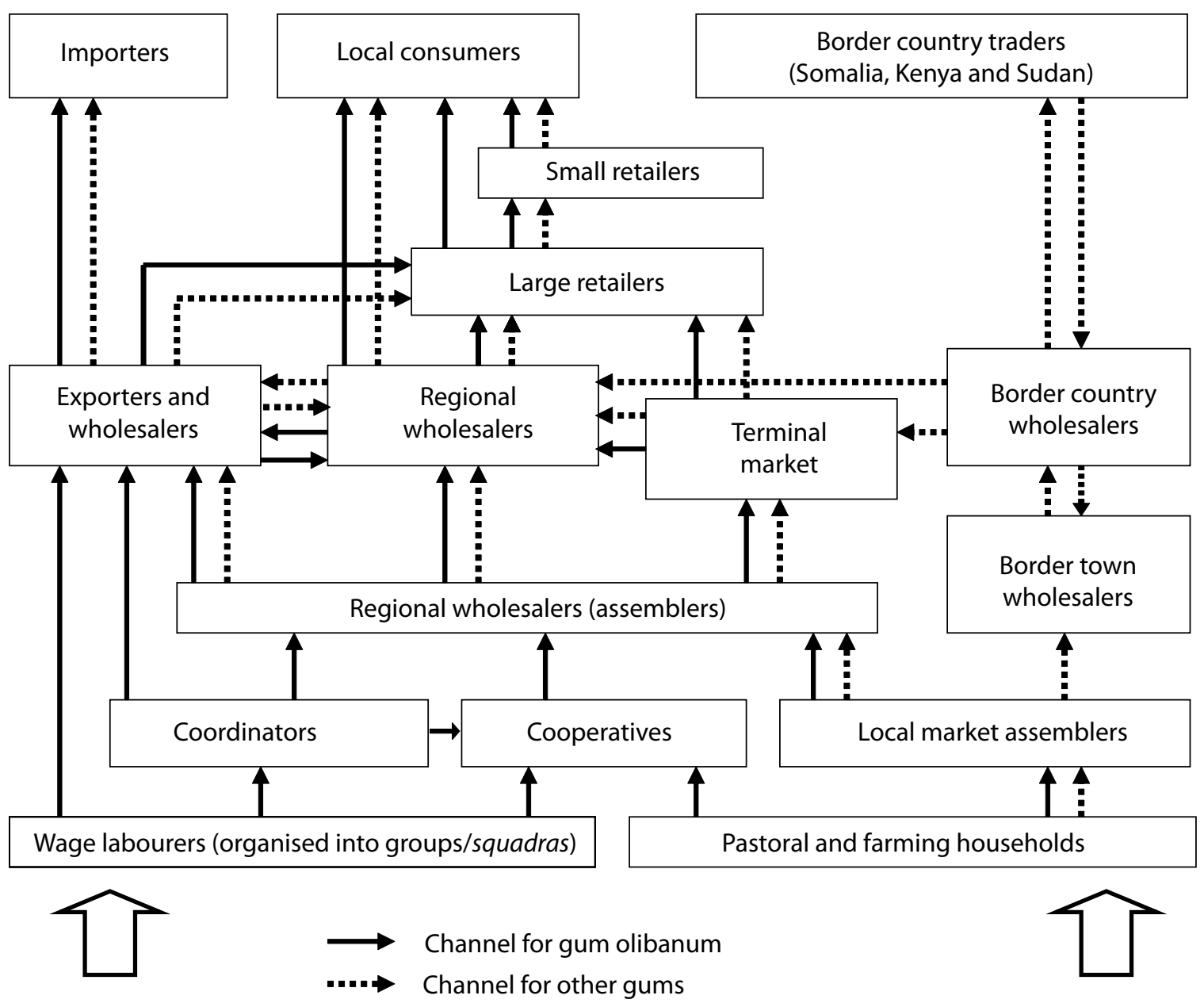

Figure 3. The value chain of gums and resins marketing in Ethiopia

Source: Market survey of 2007

cooperatives. The coordinators are the ones who sign official agreements with companies or cooperatives to provide labour. Most of these labourers come from places outside the forest area. The second group comprises local farming or pastoral and agro-pastoral households who are either members of a cooperative or who individually collect and sell gums and resins. The buyers from farming households are primarily small shops in rural towns or cooperatives. Small shop owners assemble products and sell them to bigger traders and wholesalers. The products then flow through different channels until reaching 1 of 3 main end points: importers, local consumers or illegal wholesalers to neighbouring countries. Most of the product is destined for the export market. The domestic market component of the NGPME, for example, accounts for about a third of its product volume and a tenth of the total value.

\subsubsection{Primary value chain actors}

The primary value chain activities include inbound logistics, operations, outbound logistics and marketing and sales. The objective of actors engaged in primary activities in the value chains is to create value that exceeds the cost of providing the product, thus generating profit. The study identified the following primary value chain actors.

- Farmers. These are farming or agro-pastoral and pastoral households located in the resource area and engaged in collecting and selling gums and resins, either individually or through cooperatives.

- Cooperatives. These are legal entities established by farming (in some cases also non-farming) households residing in the production areas. They include cooperatives that specialise in gum production as 
well as multipurpose cooperatives that also buy and amass products from members, and sell them to other buyers.

- Coordinators. These are individuals who act as a commission agent for companies or cooperatives to supply labour for tapping and collecting gums and resins from concession areas owned by companies or cooperatives. They sign formal agreements with companies or cooperatives regarding the rate of payment based on type and quality of product produced per quintal and modalities of payment.

- Daily labourers. These are young men experienced in tapping and collecting, and mainly from Northern Ethiopia. They organise themselves into groups (squadras) and seasonally migrate to the production sites. Other groups of daily labourers are involved in the loading and unloading and in the cleaning and grading work for companies during the storage, processing, grading and marketing of gums and resins. Those involved in loading and unloading are men whereas sorting and cleaning is exclusively done by women.

- Squadra leaders. These are leaders of teams of day labourers. These young men are employed by cooperatives or companies to collect gums from trees. The squadra leaders are the ones that negotiate and agree with employers of the team, and are responsible to select, recruit, pay and monitor the work of the team. In some cases, the leaders subcontract tasks from cooperatives and companies, and employ their own groups.

- Shops. These are small shops that buy gums and resins in small quantities from individual farming households and sell the hand tools necessary for the collection and processing of gums and resins (e.g. sharp metal tools called mingaf used for tapping, knives to separate bark and other impurities from the products, sieves for cleaning).

- Enterprises (companies). These are either private or state-owned enterprises engaged in the production and/or marketing of products. Some enterprises engage in both whereas others are involved only in marketing.

- Transporters. Transporters are individuals or companies involved in transporting raw products from the production sites to field stores and from field stores to regional and national storage and processing facilities. They also transport processed products to ports.
- Local market assemblers. These actors collect products from small local and village markets, and amass and sell them to exporting companies or to individual wholesalers.

- Wholesalers. These are further classified into 5 types.

o Regional wholesalers - assemblers. These actors buy products from cooperatives, local assemblers and in some cases from coordinators and wholesale the larger part to the terminal market and the smaller part to the region and neighbouring regions. These actors are common in major production regions notably in Tigray.

o Regional wholesalers - distributors. They distribute the product to the various customers from the terminal market or neighbouring regions. Distributors are common in non-producing regions.

o Terminal market wholesalers. They are the main wholesalers at Merkato terminal market in the capital city, Addis Ababa. Other than the government-owned enterprise and some known private companies, only half a dozen private wholesalers were observed at Merkato even though records show that more than 30 companies are involved in exporting gums and resins from Ethiopia.

o Border town wholesalers. They are Ethiopian traders operating in border towns in major producing areas and participating in the illegal import and export of gums and resins across the borders with Kenya, Somalia and Sudan.

o Wholesalers from neighbouring countries. These actors are citizens of neighbouring countries buying and exporting from and importing to Ethiopia across borders; they usually trade illegally.

- Exporters and wholesalers. These actors export gums and resins legally. Their main export product is Tigray type gum olibanum. Two groups can be distinguished: those that participate only in marketing/ exporting, and those that participate in both production and marketing. Exporters also wholesale products that do not meet export standards in the local market.

- Retailers. There are 2 categories of retailers based on the volume of sale and customers. The first are large retailers who buy from wholesalers and sell to small retailers or consumers. Their unit of product sold per transaction is more than $0.5 \mathrm{~kg}$. Most of them have shops and are licenced by the Trade and Industry 
Office. However, none of them specialises in marketing of gums. The second group consists of small retailers that sell smaller units of the product per transaction, often less than $0.5 \mathrm{~kg}$. Some have shops, but most of them sell outside, along roadsides.

- Brokers. Brokers operate at 2 levels. At the local level, individuals work for either major regional buyers or for small shops in rural towns that link individual producers to buyers. They are common in southern Ethiopia where the involvement of individuals in the production and marketing of gums and resins is more pronounced. The second level is at the terminal market. At this level, brokers facilitate transactions between wholesalers and retailers by providing information; their expertise is in the selection and identification of different types and qualities of gums. They receive a commission (marketing fee) per quintal usually from buyers, and in some cases from sellers as well.

- Importers. These are legal foreign buyers who receive the commodity through their agents. However, importers from some countries, such as China, come to Ethiopia and negotiate prices directly with the exporters.

- Consumers. Consumers are the end users of the commodity in raw or processed form, either in Ethiopia or abroad. Domestic consumers are mainly religious institutions, particularly the Ethiopian Orthodox Church, which use frankincense for religious ceremonies, and households, which use it for coffee and traditional ceremonies.

\subsubsection{Actors supporting the value chain}

The primary value chain activities described above are facilitated by various support activities. These relate to procurement, technology development, firm infrastructure and human resources management. There are 10 main actors involved in these support activities.

- Research centres/institutes are mandated to conduct research on the production and marketing of gums and institutional aspects and present their findings to policy makers and planners.

- The Cooperatives Promotion Office is mandated to facilitate the establishment, legalisation and management of cooperatives. It has offices from federal to district levels.

- Financial institutions. Banks are involved in facilitating transactions between exporters and importers in export marketing, besides providing credit to private companies and the state-owned enterprise.

- Higher educational institutions (universities and colleges) train individuals in forest management, forest product handling, processing/value-adding and marketing.

- The Transport and Trade Office issues and renews trade permits and authorises individuals and companies/ enterprises engaged in the marketing of gums and resins.

- The Agricultural and Rural Development Office issues permits to tap trees and regulates the transportation of forest products from production to marketing sites.

- The Environmental Protection and Land Administration Office at regional government level regulates access to forest land by issuing permits for forest concessions. But at district level, its operations are often superseded by the District Agriculture office.

- The Ethiopian Customs Authority facilitates the transaction and transfer of commodity exports by issuing export permits and registering all transactions in a database. However, its documentation hardly distinguishes between various gums and resins, which are sometimes registered together as one product.

- The Ethiopian Quality and Standard Authority is tasked with developing and checking the standards and grades of gums for export and provides quality certification. But its involvement in grade setting and quality control remains nominal.

- The Export Promotion Agency is mandated to work on promoting export activities of the country. Similarly, its contribution in practice is yet to be seen.

\subsection{Entry barriers}

Product differentiation and entry barriers analysis are elements of the market structure analysis. But companies' entry to the production process is highly regulated as it requires getting concession rights from the state. In addition, the small amount of capital, basic technological requirements and the lack of product differentiation (since every producer makes similar products that will be sorted into similar grades) are characteristics of gums and resins production in the country. Thus, there are no entry barriers due to capital, use of technology or product differentiation. Only the harsh environment of the production sites and the relatively narrow profit margin for producers discourages many. The marketing aspect is free. Thus many agencies do get involved in marketing. 
Gums and resins are classified into grades according to colour, size, impurity content, source area and shininess. The other major important criteria of classification, oil content and source tree species, have not been explicitly considered in the market.

The major entry barriers to production and marketing in this sector are of three types.

- Natural environmental barriers. These are related to the location and nature of the trees. Production areas are arid, hot and remote; water supply and health facilities are lacking and there is a high incidence of malaria. The topography is rugged and some source species are thorny.

- Socio-political barriers. Security and stability problems occasionally arise in the eastern part of the country, particularly in Somali Region, as a result of disputes amongst locals/clans. Such conflicts disrupt supply of products.

- Capital and legal barriers. Tapping involves little more than a minor input and experience in tapping. However, some regional governments require that those involved in tapping show a certain amount of capital and recruit foresters to get concessions to forestland as investors. Meeting such requirements is easy for companies, but very difficult for communities.

\subsection{Market conduct}

Market conduct refers to the behaviour of the participants in the physical movement of the commodity and information flow from the point of preproduction to consumption. It shows the strategies that participants adopt to gain competitive advantage, and examines buying and selling methods, interactions and relations between actors in the value chain. One such activity in the marketing of gums and resins is adding value through bulking and cleaning.

\subsubsection{Product storage, processing, grading and transportation}

Gum production and marketing include various value-adding activities, the most important of which are drying (also called drainage), cleaning, sorting and grading.

- Drainage. This is the immediate value-adding activity after gums are collected from trees. It is done mainly in 2 stages: at the production site under ventilated grass-roofed shades and in huge ventilated storehouses in major cities.

- Cleaning and impurity separation. This involves removing sand, bark, dirt and other foreign materials from the product. The separation is done manually with the help of a knife.

- Sorting and grading. During and after the cleaning, the products are sorted into grades. Grades are based mainly on the size and colour of the granule or tear. The grading systems for Tigray type frankincense has 5 grades, with grades 1 and 4 having each two subgrades (Table 2). Grading systems for gum olibanum and for gum myrrh are more developed than for other products. The grading system for gum myrrh is similar to that for gum olibanum, except that Grade 1 A myrrh is bright red in colour and grade 1B is brown. But the quality within grades is expected to be fairly similar. It is assumed that there is considerable difference in grades between gums for export and those for the domestic market. The 3 highest-quality grades of gum olibanum are exported, and, since recently, some Grade 4 product is exported to China. The rest is sold in the domestic market. Tigray type frankincense Grade 5 is further divided into different denominations and sold in the local market under various names.

- Storage and transportation. The products are stored by marketing agents at various levels (before grading in big stores and before the graded product is sold to consumers). Products are transported from the resource area to grading centres for processing and then to buyers abroad. Products for domestic markets are redistributed from the central market to local consumers in the different regions. The average cost

Table 2. Grading system for Tigray type gum olibanum

\begin{tabular}{lll}
\hline Grade & Subgrade & \multicolumn{1}{c}{ Description } \\
\hline 1 & 1A & Size: $\geq 6 \mathrm{~mm}$; white \\
& Size: $\geq 6 \mathrm{~mm}$; creamy white \\
2 & & Size: $\geq 4<6 \mathrm{~mm}$; white \\
3 & & Size: $\geq 2<4 \mathrm{~mm}$; mostly white \\
4 & $4-$ special & Any size; brown \\
& $4-$ normal & Any size; black \\
& & Powder and bark \\
\hline
\end{tabular}

Source: Fitwi and Lemenih (2010) 
of transportation for a quintal of gums per $1000 \mathrm{~km}$ increased slightly from 2007 to 2010. Improvements in road infrastructure might have offset the rise in fuel prices.

\subsubsection{Price determination and commodity transfer}

Often the price of frankincense is set by volume (quintal) and product type (quality of the product - granule size, colour and amount of impurities) collected before the actual process of collecting the product begins, in the case of companies and cooperatives. White frankincense fetches a much higher price than black frankincense. These prices are negotiated, but often the companies set the limits. Individual producers do the collection by themselves and negotiate price with buyers. Payments are often made in cash, though in some cases they are made in kind: Collectors can agree to a percentage of the collected product, for example, in some areas cooperatives agree to a $50 \%$ share). When payments are in kind, they are done afterward. When payments are made in cash by companies and cooperatives, payments are carried out in 2 ways, immediate payment or collective and periodic payment. Immediate payment is preferred by loosely organised groups of tappers who prefer to cover their cost of living, to complete tapping of an area in a relatively short period of time. These groups require immediate payment upon delivery of the product, and often payments are made to individual tappers. Under the immediate payment mechanism, unorganised farming households and nomads sell products in nearby markets to assemblers (traders) or enterprises. Buyers and sellers negotiate the prices and payment is made in cash. In some remote areas in the southern and eastern parts of Ethiopia, farmers and nomads sell products in kind to small shop owners in villages and small markets.

Under the collective and periodic payment system, day labourers negotiate with their squadra leaders who in turn negotiate with the coordinator. The coordinator then makes an official agreement with an enterprise or a cooperative that is employing the day labourers, regarding the rate and method of payments. Often payments are made after the products have been collected and transferred to the company or cooperative stores. If the company covers part of the workers' living costs during the collection season, that amount will be deducted from the final payment at the end of the collection season, after several months.
Similarly, farming households who collected gums individually and deliver their products to the cooperatives are paid after the cooperatives have sold the product, and after deducting costs and service charges incurred by the cooperatives. But those who sell products to small shops in rural towns get paid either in cash or in kind. Some traders who bulk these products then transport them to Addis Ababa along with other merchandise and sell them to private exporting companies. Some exporters pay only a down payment and make final payment after the product is exported. This is particularly common in eastern and southern Ethiopia where exporting companies also support local traders in the region by providing credits and storage facilities for their products. Exporting companies also trade much-needed consumer goods in the major gum producing areas. These traders have even begun to provide credits to rural shop owners to buy and bulk gums and resins from individual farming households.

An examination of the relative bargaining power of agents revealed that farming households or nomads and exporters are more often price takers than other agents.

\subsubsection{Measuring units and packing materials}

Transactions between farming households and nomads and rural assemblers are made using balances. In towns, spring balances are widely used for retailing products. Companies and enterprises use new bags made from cotton cloth as packing material for exporting. But in the regions, small traders and assemblers most often use bags made from synthetic materials. In some cases, these bags have contained chemical fertilisers. This has had a negative impact on product quality.

\subsubsection{Gender aspects of the value chain}

There are considerable differences in the involvement of men and women in activities along the value chain and in the major producing areas. In northern Ethiopia, only men collect gums from trees in the forests because of the remoteness and harsh environment of the production area, whereas in southern and eastern Ethiopia, women and children often collect gums and resins whilst they look after livestock. Cleaning and sorting/grading of the crude gum is undertaken exclusively by women. Women also dominate retailing of frankincense to consumers in major cities and towns after buying from large retailers. Women employed in these activities, especially in cleaning 
and sorting, are often the poorest of the poor, which indicates the importance of this activity for marginalised, poor urban women.

\subsection{Market performance}

The different gums and resins exhibit variations in market price and marketing margins for producers. The share of producers from the marketing margin of gums and resins ranged from 19\% for frankincense in 2010 to $75 \%$ for myrrh in 2007. Marketing of Tigray type frankincense is relatively well developed as it accounts for more than $90 \%$ of the total export volume of gums and resins. A preliminary marketing margin analysis for the shorter marketing channel of Tigray type frankincense indicates that producers - especially those not in cooperatives - did not benefit from higher export prices in 2010, as their share of the marketing margin remained low (34.5\% in 2007 and $19.1 \%$ in 2010). Exporters' share of the marketing margin was $41.1 \%$ and $31.4 \%$ in 2007 and 2010, respectively (Table 3).

\section{Conclusion and recommendations}

The collection of gums and resins at the grassroots level is mainly done by private companies, although farming households and agropastoral communities are also involved. Gum-producing cooperatives either get their members to collect the products or hire labourers for tapping and collecting. The labourers are paid either in cash or in kind, depending on the agreement they reach with the cooperatives. Enterprises, by contrast, employ labourers to work in their concession forests. Day labourers or self-organised teams of working men are paid an agreed amount of money per quintal of product collected, with payment made when the job is completed.

Access rights differ across regions. For example, access is not restricted in southern Ethiopia, but in the Amhara Region, unless organised into legalised cooperatives, local community access to forests to tap gums and resins is highly restricted. Only licenced companies and producers that form specialised gum-producing cooperatives are allowed to tap trees in concession areas. However, the same community members can obtain permits to cut down trees (often gum-producing ones) for house construction or reconstruction. Given that local authorities' capacity to protect dry forests is extremely underdeveloped, these exclusionary measures serve only to aggravate illegal conversion of forestlands to croplands.
Therefore, some form of institutional intervention is required to address this; and this should be combined with training and extension activities to support communities in gaining access to the forests along with a concomitant responsibility to sustainably manage this resource.

As shown in Table 3, there are many advantages in assisting farmers to form cooperatives, and in building the capacity of cooperatives so they can become important actors in the marketing chain. With further assistance, these primary cooperatives could form unions that could become engaged in exporting gums and resins, as has been the experience with coffee. However, development of unions must be accompanied by capacity-building activities and mechanisms for transparency and internal governance of unions to avoid corruption and elite capture.

The technologies used in the collection of gums and resins, and attempts to add value, have remained largely unchanged for decades. Value-adding activities are limited to cleaning, sorting and grading. Therefore, it is necessary to improve production and processing aspects. Attributes considered in grading gums and resins are size, colour, source area and content of impurities. Research is needed into other attributes, such as source tree species and oil content, to ensure that products are graded according to their essential oil content.

Most of the product exported comes from state-owned and private export companies and, to some extent, from cooperatives that bulk and sell gums and resins collected by farming communities. The export volume and value of gums and resins have increased in recent years. This has led to increased importance of the export market in relation to the domestic market. The significant devaluation of the Ethiopian birr means the export value of gums and resin is also growing. However, our preliminary assessment shows that producers are not necessarily benefiting from this growth: in 2006/07, producers' share of the marketing margin ranged from $25 \%$ to $75 \%$. For farmers who were selling to companies on an individual basis, the margin for export-grade Tigray type gum olibanum was 34.5\% in 2006/07 and it dropped to $19 \%$ in 2010. By contrast, cooperatives that were bulking and selling frankincense had a profit margin of $42.6 \%$, indicating the advantages for producers of working through cooperatives to increase their bargaining power. Thus, assisting producers to form cooperatives 
Table 3. Prices, costs and margins of Tigray type gum olibanum during 2 production years

\begin{tabular}{|c|c|c|c|c|c|c|}
\hline & \multicolumn{2}{|c|}{$2006 / 2007$} & \multicolumn{2}{|c|}{$\begin{array}{l}2009 / 2010 \\
\text { farmer sales }\end{array}$} & \multicolumn{2}{|c|}{$\begin{array}{c}2009 / 2010 \\
\text { cooperative sales }\end{array}$} \\
\hline & $\begin{array}{c}\text { Price } \\
\text { (birr/Qt) }\end{array}$ & $\begin{array}{l}\text { Margin } \\
(\%)\end{array}$ & $\begin{array}{c}\text { Price } \\
\text { (birr/Qt) }\end{array}$ & $\begin{array}{l}\text { Margin } \\
(\%)\end{array}$ & $\begin{array}{c}\text { Price } \\
\text { (birr/Qt) }\end{array}$ & $\begin{array}{c}\text { Margin } \\
(\%)\end{array}$ \\
\hline \multicolumn{7}{|l|}{ Producers (Collectors) } \\
\hline Selling price & 415.00 & 34.52 & $650.00^{\mathrm{a}}$ & 19.13 & $1450.00^{*}$ & 42.67 \\
\hline \multicolumn{7}{|l|}{ Wholesalers/Exporters } \\
\hline Buying price & 415.00 & & 650.00 & & 1450.00 & \\
\hline Selling price (average value of all grades) ${ }^{b}$ & 1202.35 & 100.00 & $3398.00^{b}$ & 100.00 & $3398.00^{b}$ & 100.00 \\
\hline Marketing margin & 787.35 & 65.48 & 2748.00 & 80.87 & 1948.00 & 57.33 \\
\hline Marketing cost & 293.60 & 24.42 & 961.00 & 28.28 & 881.00 & 25.93 \\
\hline Fee for coordinator & 35.00 & 2.91 & 80.00 & 2.35 & 0.00 & 0.00 \\
\hline Loading and unloading cost & 11.00 & 0.92 & 6.00 & 0.18 & 6.00 & 0.18 \\
\hline Transportation cost (Shire-Addis Ababa) & 40.00 & 3.33 & 60.00 & 1.77 & 60.00 & 1.77 \\
\hline Cleaning and sorting cost & 76.00 & 6.37 & 100.00 & 2.94 & 100.00 & 2.94 \\
\hline Packaging material and marking & 13.00 & 1.08 & 15.00 & 0.44 & 15.00 & 0.44 \\
\hline Transportation cost to Djibouti & 60.00 & 4.99 & 80.00 & 2.35 & 80.00 & 2.35 \\
\hline Royalty cost (except Grade 5) & 33.60 & 2.79 & 90.00 & 2.65 & 90.00 & 2.65 \\
\hline Other costs (store, staff, quarantine, etc.) & 25.00 & 2.03 & 530.00 & 15.60 & 530.00 & 15.60 \\
\hline Profit margin & 493.75 & 41.07 & 1787.00 & 52.59 & 1067.00 & 31.40 \\
\hline Importers (Grades 1 to 4 ) & 1202.35 & 100.00 & 3398.00 & 100.00 & 3398.00 & 100.00 \\
\hline
\end{tabular}

a When a company bought from a cooperative, the reported selling price in the 2010 production season was 1450 birr/qt; by contrast, companies paid on average 650 birr/qt for farmers or groups producing for companies.

b Girmay and Lemenih (2010) report that a quintal of unprocessed Tigray type gum olibanum on average comprises about 15\% Grade 1A, 5\% Grade 1B,7\% Grade 2, 3\% Grade 3, 20\% Grade 4 Special, 22\% Grade 4 Regular, and 28\% Grade 5 (see Table 2 for grade characteristics ). According to NGPME (2010), the 2010 export price of the export grades (except Grade 5) were USD 500, 380, 370, 320, 230 and 205 or birr $6750,5130,4995,4320,3105$ and 2768, respectively. The average local market value of Grade 5 (for domestic use) is birr 1500 per quintal. The weighted mean value of an unprocessed quintal is then $\{(0.15 \times 6750)+0.05 \times 5130)+(0.07 \times 4995)+(0.03 \times 4320)+(0.20 \times 3105)+(0.22 \times$ 2768) $+(0.28 \times 1500)=3398.21$

and building cooperatives' technical and administrative capacity to increase production, to add value and to improve their internal governance are important activities. Strong cooperatives that win the confidence of their members can easily form unions that can legally engage in export activities. This will in turn significantly increase profit margins for producers, constituting an economic incentive for producers to manage dry forests sustainably.

Similarly, export companies should form an association to increase their bargaining power, and to contribute towards improved governance of the marketing system. Based on experience in other countries, such associations could be involved in jointly setting prices for export (thereby avoiding competition between companies for the same customer), in ensuring timely delivery of products at the required volume and quality to buyers, and in building the technical and managerial capacity of their members to produce more and quality products. It will also improve their capacity to engage policy makers and non-state actors interested in supporting them. The overall efforts of such an association should be directed 
towards enhancing the systemic competitiveness of the entire value chain. This would improve exports and may significantly increase export earnings. With significant increases in export prices, the prices that producers get are also likely to increase. Increased export volume, export value and profit margins will constitute an economic incentive for local communities and governments to produce more gums and resins from sustainably managed dry forests.

\section{References}

Department of Planning and Economic Development (DoPED) 2009 Annual report 2008/2009. Central Zone Planning and Economic Development, Axum, Tigray Region, Ethiopia.

Fitwi, G. and Lemenih, M. 2011 Product handling and quality control of gums and resins. In: Lemenih, M. and Kassa, H. (eds) Opportunities and challenges for sustainable production and marketing of gums and resins in Ethiopia, 43-61. CIFOR, Bogor, Indonesia.
Institute of Development Studies 2002 Conceptual studies on global value chains. http://www.ids.ac.uk/ids/global/ valchnconcep1.html [29 December 2010].

Lemenih, M. and Kassa, H. 2011 a Gums and resins of Ethiopia. CIFOR, Bogor, Indonesia.

Lemenih, M. and Kassa, H. (eds) 2011 b Opportunities and challenges for sustainable production and marketing of gums and resins in Ethiopia. CIFOR, Bogor, Indonesia.

McCormick, D. and Schmitz, H. 2002 Manual for value chain research on home workers in the garment industry. Institute of Development Studies, Brighton, UK.

Mesfin, T., Olschewski, R., Kleinn, C. and Gebrehiwot, K. 2007 Economic analysis of closing degraded Boswellia papyrifera dry forest from human interventions: a study from Tigray, Northern Ethiopia. Forest Policy and Economics 9(8): 996-1005.

Natural Gum Production and Marketing Enterprise (NGPME) 2010 Annual report for the 2009/10 Ethiopian fiscal year. NGPME, Addis Ababa, Ethiopia.

Wilson, R. 1977 The vegetation of Central Tigre, Ethiopia, in relation to its land use. Webbia 32: 233-270. 